\title{
Analysis and Research on Employment \\ Predicament of University Students
}

\author{
Qingjun $\mathrm{Wu}$ \\ Operation and Management College \\ Qufu Normal University \\ Rizhao 276826, China
}

\begin{abstract}
The employment problem of the university students has always been one of the social focuses. The reasons of employment predicament of university students are not due to a single factor, but are results of many factors working together. The author analyzes the macroscopic and microscopic reasons of employment predicament of the university students, then putting forward measures to solve this problem from the angle of government, enterprises, universities and students respectively.
\end{abstract}

Keywords: Employment of University Students, Analysis of Reasons, Research of Countermeasures

\section{Employment Predicament that University Students Are Faced with At Present}

Entering into the 21st century, the students in ivory tower suddenly discover that looking for work is no longer an easy matter and employment of university students has become a focus of society. The number of national university graduates only was 1,040,000 in 2001 which, however, has reached about 5,000,000 in 2007.At the same time, the university undergraduates who wait for jobs are also on the increase year by year. The number has increased from 340,000 in 2001 to an average number of more than 1,000,000 per year starting from 2007 to now.According to Educational Department's statistics, the average employment rate of national university graduates was only around $70 \%$ since 2001 .Besides the large number of the students who graduates and seek jobs every year, there are also considerable graduates of previous years who are still unemployed, which certainly intensify the difficulty in solving the problem of university students' employment. University graduates flood into employment markets in such a large amount that every graduate has experienced the panic of employment in person.

\section{Analysis to the Reasons of Employment Predicament of University Students}

\subsection{Macroscopic Reasons that Lead to Employment Predicament of University Students}

\subsubsection{Social factors}

2.1.1.1The total amount of labor supply overruns that of labor demand of society, which leads to gross unemployment.

According to the economic blue book recently issued by Chinese Social Science Institute in 2007, the unemployed urban population will reach more than $25,000,000$, while on the other hand employment positions has increased only by $10,000,000$ in 2007 , which will leave a gap of supply over demand more than $15,000,000$. At the aspect of social demand for employment position, the overall employment elasticity of China has a gradual dropping tendency, that is, contributions that economy growth makes to employment growth are less and less, demand for labor has difficulties in growing while supply of labor are relatively excessive.

\subsubsection{Employment Peaks of Kinds of Employment Main Body interact together.}

Employment situation is extremely stern at present, that is, employment of the urban newborn labor force, the rural surplus labor force, the laid-off workers, the veterans and the university graduates interweave mutually, all of which aggravates the situation of university students' employment.

\subsubsection{Employment Positions suitable for university students are far from enough at present.}

High-tech industry is an important impellent of modern economic development. And in Chinese domestic market there is a huge demand for the high tech products, the majority of which, however, are imports from overseas, only a few made at home. 
With its insufficient development and not big scale, the lag of domestic high-tech industry results in the lack of high tech industries' posts which on the other hand is the main battlefield to solve the employment problem of university students.

\subsection{2 governmental reasons}

2.1.2.1The employment problem of university students is directly caused by the fact that university enrollment increases too fast.

Since1999 when Chinese University started increasing enrollment on a large scale, the higher education has been entering into an accelerative development period. The number of ordinary university students has increased from 3,400,000 in 1998 to 18,000,000 in 2007 after successive years' increase in enrollment. Including adult and network students, the overall scale of national higher education has broken through $25,000,000$ with a gross enrollment rate above $23 \%$, which indicates high education has entered into its popularizing period.Growth rate of university enrollment exceed that of employment position.

\subsubsection{2}

The direction and scale of university enrollment is separated from those of the employment position.

It was too hasty and careless for the national education department to formulate the policy of increasing university enrollment in 1999 since it only aimed at constantly increasing enrollment number without insufficient evaluation on the overall and long-term demand for social talents.The oversimplified behavior finally leads to the fact that the so-called talents fostered by universities not only surpass social demand in quantity but also cannot adapt to social demand in quality.

\subsection{Microscopic Reasons of University Students' Employment Predicament}

\subsubsection{Enterprises' Reasons}

Many enterprises lack scientific standards when they select talents and just look for persons when they lack ones, not using any human resources management technology. For a long time, in their fast development period such enterprises select talents without any development plan of human resources just like putting out fire only when there is any.With no arrangement for organization and position and no position demand plan, most enterprises select talents on the basis of experience and feeling which is unscientific. Such conducts have limited enterprises' development and affected the success ratio of selecting talents.

\subsubsection{Universities' Reasons}

2.2.2.1Universities have no marketing consciousness, lack marketing survey and analysis as well as foresight, which are all necessary for establishing majors.

Many universities, without considering their actual level practically, set up similar majors, which causes talents surplus and thus adds employment difficulty for university students.

\subsubsection{Universities' career guidance is not proper.}

In their crucial phase of entering into society, university graduates know far from enough about society and feel puzzled and confused about their work and future, which accordingly requires their schools to offer them helpful advice on occupation plans, but unfortunately many universities have done rather poorly in guiding university student's career.

\subsubsection{The students' knowledge structure taught in universities has flaws.}

Knowledge students learn in university is too theoretical and obsolete to keep pace with the development of time and society.

\subsubsection{Students' Reasons}

\subsubsection{University students have misunderstanding on employment.}

Some university students hold too high expectation for themselves, such as hoping to work in a high-paid company or to occupy an important position in a company and etc., all of which are impractical.Graduates pay all their attention to overseas-funded enterprises, governmental agencies and so on, while unwilling to work in basic units. Their impractical behaviors only make them end up in getting no job even at the time of graduation.

\subsubsection{University student's ability has flaws}

At present university students have insufficient comprehensive qualities and necessary abilities, which is vividly justified by their lack in practical social work experience, in abilities to deal with realistic problems and in hardworking and enterprising spirits, their difficulty in cooperating and communicating with others, their arrogance and impetuousness etc.

Except book knowledge, their limited interests put them in disadvantage in the position competition. 
.Although there is a high demand for the high-tech and high-skill talents in recent years, the graduates still lose this good employment opportunity due to their shortage of work experience and skills.

\section{Countermeasures of Solving University Students' Employment Predicament}

\subsection{Government's measures}

\subsubsection{Expansion in Employment}

The fundamental way to solve employment's problem of university students is nothing but to vigorously develop economy, unceasingly increase employment's posts and expand employment channels.Government should increase posts for university graduates by adjusting industrial structure, especially by supporting high technology industries.

3.1 .2 Excavating employment information vigorously and providing more channels and platforms for employment of university students.

The quality of analyzing labor demand information should be improved, and especially the analysis of demand for university students should be emphasized. Employment information resource should be integrated together and network advantage should be fully used so as to regularly issue the employment information and policy.

\section{1 .3 Expanding population of graduates enlisting in army and increasing enrollment of postgraduates}

A considerable number of excellent graduates join the People's Liberation Army, which is helpful to improve the quality of army as well as university students and to a certain degree alleviates the pressure of employment. Expanding enrollment of graduate student is helpful to cultivate high-level talents and put off the time of their employment.

\subsection{The enterprise's Measure}

Enterprises should formulate proper standards for selecting talents and recruiters according to their own scale, nature and development conditions.

\subsection{Universities' Measures}

3.3.1 Universities should properly forecast the specialty demand of the coming years so as to adjust specialties and curriculum according to market demand.

3.3.2 Universities should adjust teaching materials, reform teaching process and explore new teaching methods.

Universities should reform traditional talent training pattern, integrate the cultivation of innovative and career consciousness into the teaching process, thus finally enabling students to be multi-skill talents of firm foundation, high quality and strong ability according to the demand of social development.

Universities should perfect the practice teaching system and make sure that students obtain both diploma and professional credentials at the time of graduation.

3.3.3 Universities should perfect career guidance system as soon as possible.

Universities should establish occupation instruction organization to instruct students to conduct self-appraisal and formulate seeking work strategy.

3.3.4 Universities should make detailed investigation on employment rate of each specialty every year in order to adjust specialty direction to society demand.

\subsection{Students' Measure}

3.4.1 University students should make appropriate professional plans.

University students should keep enhancing themselves, striving for harmonious development of their potential and occupation skills.

3.4.2 University students should transform employment concept and mind-set.

University students should eliminate impractical ideas, instead of which they should start from ordinary worker, seeking development in basic unit and creating career in hard places.

3.4.3 University students should have an accurate orientation and a clear realization of their own quality and condition. And instead of comparing blindly, they should look for companies suitable to them according to their own condition.

3.4.4 University students should work hard to extend their qualities and improve their comprehensive abilities.

University students should have a reasonable knowledge structure, a innovative spirit, a flexible thinking mode, good psychological quality, tenacious self-control, firm faith, the ability of processing information and handling interpersonal relationship and so on. 


\subsubsection{Increase social practice experience}

University students should take part in social practice in vacation by unifying theory knowledge with practical work to enhance their ability of processing problem and accumulate work experience.

3.4.6 University students should grasp opportunities of employment with the aid of kinds of ways.

University students should have confidence and courage and be able to study and weigh the situation to find out the appropriate employment position. And by taking advantage of talent meeting and network resources, they can seize the hard-won employment opportunity and take the initiatives to market themselves.

In summary, the reason of employment predicament is not due to a single factor, but is the result of kinds of factors together.Therefore in order to solve the difficult problems of university students' employment, we should combine the enthusiasm of all sides to form a concerted force with which the employment problem of university students can be solved fundamentally.

\section{References}

China statistical labor yearbook 2006, population and employment statistics department of national statistic bureau( 2006).

Chinese population and employment statistics yearbook 2007, china statistic bureau(2007).

Work and social security department website, network monitor center of China labor market information, http://www.lm.gov.cn. 